\title{
Waves off Gopalpur, northern Bay of Bengal during Cyclone Phailin
}

\author{
M. M. Amrutha ${ }^{1}$, V. Sanil Kumar ${ }^{1}$, T. R. Anoop ${ }^{1}$, T. M. Balakrishnan Nair ${ }^{2}$, A. Nherakkol ${ }^{2}$, and C. Jeyakumar ${ }^{2}$ \\ ${ }^{1}$ Council of Scientific and Industrial Research - National Institute of Oceanography, Dona Paula 403004, Goa, India \\ ${ }^{2}$ Indian National Centre for Ocean Information Services (Ministry of Earth Sciences), "Ocean Valley”, Pragathi Nagar (BO), \\ Nizampet (SO) 500090, Hyderabad, India \\ Correspondence to: V. Sanil Kumar (sanil@ nio.org)
}

Received: 6 March 2014 - Revised: 19 May 2014 - Accepted: 31 July 2014 - Published: 2 September 2014

\begin{abstract}
The wave statistical parameters during Cyclone Phailin which crossed the northern Bay of Bengal are described based on the Directional Waverider buoy-measured wave data from 8 to 13 October 2013. On 12 October 2013, the cyclone passed within $70 \mathrm{~km}$ of the Waverider buoy location with a wind speed of $59.2 \mathrm{~m} \mathrm{~s}^{-1}$ (115 knots), and during this period, a maximum significant wave height of $7.3 \mathrm{~m}$ and a maximum wave height of $13.5 \mathrm{~m}$ were measured at $50 \mathrm{~m}$ water depth. Eight freak wave events are observed during the study period. The ratio of the maximum wave height to significant wave height recorded is found to be higher than the theoretical value and the ratio of the crest height to wave height during the cyclone was 0.6 to 0.7 . The characteristics of the wave spectra before and after the cyclone is studied and found that the high-frequency face of the wave spectrum is proportional to $f^{-3}$ before the cyclone and is between $f^{-4}$ and $f^{-5}$ during the cyclone period.
\end{abstract}

Keywords. History of geophysics (ocean sciences)

\section{Introduction}

In the tropical oceans, cyclones are one of the most commonly occurring natural hazards and can have significant impact on the coast. The waves generated during cyclones govern the design of marine facilities, and hence the characteristics of the waves during cyclones are required for planning and design of offshore facilities and for planning mitigation measures. A number of studies were carried out to understand wave generation and wave growth during hurricane (Young, 2006; PrasadKumar and Stone, 2007; Xu et al., 2007; Chu and Cheng, 2008; Soomere et al., 2008; Fan et al.,
2009; Babanin et al., 2011). As of today, the largest significant wave height $\left(H_{\mathrm{s}}\right)$ measured was $24 \mathrm{~m}$ during Typhoon Krosa in $32 \mathrm{~m}$ water depth (Babanin et al., 2011). In the Bay of Bengal, the largest $H_{\mathrm{S}}$ measured is $8.4 \mathrm{~m}$ on $28 \mathrm{Oc}-$ tober 1999 during the passage of the Orissa super cyclone (Rajesh et al., 2005). A number of oil and gas platforms are planned along the east coast of India and the crest height of the wave during the extreme wave condition decides the air gap of the offshore platforms (Kumar et al., 2013).

Considering the importance of the knowledge of wave statistical parameters during cyclones, a study is carried out by analysing the wave data measured in the nearshore waters of northern Bay of Bengal during the passage of Cyclone Phailin. The objective of this paper is to study the wave spectral characteristics and the wave statistical parameters of the cyclone-generated high waves.

\section{Materials and methods}

In connection with the real-time wave data collection program, a Datawell Directional Waverider buoy was moored at $15 \mathrm{~m}$ water depth $\left(19^{\circ} 16.87^{\prime} \mathrm{N}, 84^{\circ} 57.76^{\prime} \mathrm{E}\right)$ off Gopalpur (Fig. 1) and the data collection was ongoing since February 2013. The deployed buoy drifted from its moored location on 12 October 00:00 UTC due to the impact of the cyclone and the GPS data show that the buoy remained within $100 \mathrm{~km}$ from the cyclone track on 12 October 2013 (Fig. 2). The cyclone track and the position of the buoy are presented in Table 1. The time referred to in the paper is Coordinated Universal Time (UTC) and the local time is Indian Standard Time (IST), which is UTC $+5: 30$. The data measured during $8-13$ October 2013 are analysed to study the wave 
Table 1. Cyclone position, wind speed, buoy location and wave parameters during 9-13 October 2013.

\begin{tabular}{|c|c|c|c|c|c|c|c|c|c|c|c|}
\hline \multirow[b]{2}{*}{ Date } & \multirow[b]{2}{*}{$\begin{array}{c}\text { Time } \\
\text { (GMT) }\end{array}$} & \multicolumn{2}{|c|}{ Cyclone position } & \multirow{2}{*}{$\begin{array}{r}\text { Central } \\
\text { pressure } \\
\text { (mbar) }\end{array}$} & \multirow{2}{*}{$\begin{array}{r}\text { Wind } \\
\text { speed } \\
\left(\mathrm{m} \mathrm{s}^{-1}\right)\end{array}$} & \multicolumn{2}{|c|}{ Buoy location } & \multirow{2}{*}{$\begin{array}{l}\text { Distance of } \\
\text { buoy from } \\
\text { cyclone }(\mathrm{km})\end{array}$} & \multirow[b]{2}{*}{$\begin{array}{r}H_{\mathrm{S}} \\
(\mathrm{m})\end{array}$} & \multirow[b]{2}{*}{$\begin{array}{l}T_{\mathrm{p}} \\
(\mathrm{s})\end{array}$} & \multirow[b]{2}{*}{$\begin{array}{r}D_{\mathrm{p}} \\
(\mathrm{deg})\end{array}$} \\
\hline & & $\begin{array}{r}\text { Latitude } \\
\left({ }^{\circ} \mathrm{N}\right)\end{array}$ & $\begin{array}{r}\text { Longitude } \\
\left({ }^{\circ} \mathrm{E}\right)\end{array}$ & & & $\begin{array}{r}\text { Latitude } \\
\left({ }^{\circ} \mathrm{N}\right)\end{array}$ & $\begin{array}{r}\text { Longitude } \\
\left({ }^{\circ} \mathrm{E}\right)\end{array}$ & & & & \\
\hline 9 & 09:00 & 13.5 & 92.5 & 1000 & 15.43 & 19.2812 & 84.9635 & 1055.5 & 1.1 & 13.3 & 165 \\
\hline 9 & $12: 00$ & 13.5 & 92.5 & 999 & 18.01 & 19.2812 & 84.9635 & 1055.5 & 1.0 & 20.0 & 152 \\
\hline 9 & $15: 00$ & 13.6 & 92.5 & 999 & 18.01 & 19.2812 & 84.9635 & 1048.7 & 0.9 & 20.0 & 162 \\
\hline 9 & $18: 00$ & 14.0 & 92.0 & 998 & 20.58 & 19.2812 & 84.9635 & 977.6 & 1.1 & 20.0 & 146 \\
\hline 9 & $21: 00$ & 14.0 & 92.0 & 998 & 20.58 & 19.2812 & 84.9635 & 977.6 & 1.2 & 13.3 & 172 \\
\hline 10 & 00:00 & 14.5 & 91.5 & 996 & 23.15 & 19.2812 & 84.9635 & 899.9 & 1.1 & 20.0 & 153 \\
\hline 10 & 03:00 & 14.5 & 91.0 & 990 & 28.29 & 19.2812 & 84.9635 & 855.7 & 1.1 & 18.2 & 160 \\
\hline 10 & 06:00 & 15.0 & 90.5 & 984 & 33.44 & 19.2812 & 84.9635 & 777.7 & 1.2 & 18.2 & 153 \\
\hline 10 & 09:00 & 15.0 & 90.5 & 982 & 36.01 & 19.2812 & 84.9635 & 777.7 & 1.4 & 18.2 & 155 \\
\hline 10 & $12: 00$ & 15.5 & 90.0 & 976 & 38.58 & 19.2812 & 84.9635 & 699.8 & 1.7 & 18.2 & 155 \\
\hline 10 & $15: 00$ & 15.5 & 90.0 & 966 & 46.30 & 19.2812 & 84.9635 & 699.8 & 1.7 & 18.2 & 158 \\
\hline 10 & $18: 00$ & 15.5 & 89.5 & 960 & 48.87 & 19.2812 & 84.9635 & 656.2 & 2.3 & 18.2 & 158 \\
\hline 10 & 21:00 & 15.5 & 89.0 & 954 & 51.44 & 19.2812 & 84.9635 & 614.6 & 2.2 & 18.2 & 155 \\
\hline 11 & 00:00 & 16.0 & 88.5 & 946 & 56.59 & 19.2812 & 84.9635 & 536.1 & 2.5 & 16.7 & 162 \\
\hline 11 & 03:00 & 16.0 & 88.5 & 940 & 59.16 & 19.2812 & 84.9635 & 536.1 & 2.5 & 16.7 & 156 \\
\hline 11 & 06:00 & 16.2 & 88.3 & 940 & 59.16 & 19.2812 & 84.9635 & 504.7 & 2.6 & 20.0 & 155 \\
\hline 11 & 09:00 & 16.5 & 88.0 & 940 & 59.16 & 19.2812 & 84.9635 & 457.6 & 2.8 & 10.5 & 131 \\
\hline 11 & $12: 00$ & 16.8 & 87.7 & 940 & 59.16 & 19.2812 & 84.9635 & 410.5 & 3.4 & 11.1 & 132 \\
\hline 11 & $15: 00$ & 16.9 & 87.2 & 940 & 59.16 & 19.2812 & 84.9635 & 363.0 & 3.9 & 11.8 & 132 \\
\hline 11 & 18:00 & 17.0 & 87.0 & 940 & 59.16 & 19.2812 & 84.9635 & 339.8 & 4.1 & 11.8 & 134 \\
\hline 11 & 21:00 & 17.1 & 86.8 & 940 & 59.16 & 19.2812 & 84.9635 & 316.8 & 3.9 & 12.5 & 142 \\
\hline 12 & 00:00 & 17.5 & 86.5 & 940 & 59.16 & 19.2812 & 84.9635 & 261.4 & 4.3 & 11.8 & 135 \\
\hline 12 & 03:00 & 17.8 & 86.0 & 940 & 59.16 & 19.2687 & 84.9494 & 200.7 & 5.5 & 12.5 & 141 \\
\hline 12 & 06:00 & 18.1 & 85.7 & 940 & 59.16 & 19.2096 & 84.8967 & 152.2 & 6.7 & 11.8 & 118 \\
\hline 12 & 09:00 & 18.6 & 85.4 & 940 & 59.16 & 19.0906 & 84.8352 & 83.1 & 7.0 & 11.1 & 98 \\
\hline 12 & $12: 00$ & 18.7 & 85.2 & 940 & 59.16 & 18.7963 & 84.7293 & 53.4 & 7.3 & 11.1 & 103 \\
\hline 12 & $15: 00$ & 19.1 & 85.2 & 940 & 59.16 & 18.5021 & 84.5786 & 95.8 & 5.8 & 11.8 & 56 \\
\hline 12 & $18: 00$ & 19.5 & 84.8 & 956 & 51.44 & 18.2863 & 84.5187 & 138.4 & 5.2 & 9.1 & 212 \\
\hline 12 & 21:00 & 20.0 & 84.5 & 966 & 46.30 & 18.1281 & 84.4606 & 208.1 & 4.4 & 9.1 & 208 \\
\hline 13 & 00:00 & 20.5 & 84.5 & 976 & 38.58 & 17.9914 & 84.4150 & 278.9 & 4.4 & 9.1 & 214 \\
\hline 13 & 03:00 & 21.0 & 84.0 & 990 & 28.29 & 17.8768 & 84.3647 & 349.4 & 4.4 & 9.1 & 196 \\
\hline 13 & $06: 00$ & 21.5 & 84.0 & 996 & 20.58 & 17.7795 & 84.3228 & 415.0 & 4.3 & 9.1 & 191 \\
\hline 13 & 09:00 & 21.8 & 83.8 & 998 & 18.01 & 17.7119 & 84.2892 & 457.5 & 3.6 & 8.3 & 204 \\
\hline 13 & $12: 00$ & 22.5 & 83.8 & 998 & 18.01 & 17.6460 & 84.2574 & 541.8 & 3.5 & 7.1 & 207 \\
\hline 13 & $18: 00$ & 23.0 & 83.5 & 1002 & 15.43 & 17.4855 & 84.1614 & 617.2 & 2.9 & 7.7 & 172 \\
\hline
\end{tabular}

characteristics during Cyclone Phailin. Technical details of the Directional Waverider buoy and the accuracy of the measurement are presented by Barstow and Kollstad (1991). Wave data are recorded continuously at $1.28 \mathrm{~Hz}$, and heave is measured in the range of -20 to $20 \mathrm{~m}$ with a resolution of $1 \mathrm{~cm}$ and an accuracy of $3 \%$. Wave spectrum is obtained through fast Fourier transform (FFT) with high-frequency cut-off at $0.58 \mathrm{~Hz}$ and resolution of $0.005 \mathrm{~Hz}$. Significant wave height and mean wave period $\left(T_{\mathrm{m}_{02}}\right)$ are estimated from the spectral moment. Spectral peak period $\left(T_{\mathrm{p}}\right)$ is estimated at the spectral peak. Zero-crossing analysis of the surface elevation time series is used to estimate maximum wave height $\left(H_{\max }\right)$ and $H_{1 / 3}$. Other parameters studied are spectral peakedness parameter $\left(Q_{\mathrm{p}}=\frac{2}{m_{0}^{2}} \int_{0}^{\infty} f S^{2}(f) \mathrm{d} f\right)$ and spectral width parameter $\left(v=\sqrt{\left(m_{0} m_{2}\right) / m_{1}^{2}-1}\right)$ based on spectral analysis (Goda, 1970) and maximum spectral energy density, where $m_{n}$ is the $n$th order spectral moment and $S(f)$ is the spectral energy density at frequency $f$. Mean wave direction corresponding to the spectral peak $\left(\theta_{\mathrm{p}}\right)$ and the directional width $(\sigma)$ is estimated based on circular moments (Kuik et al., 1988). The Joint North Sea Wave Project (JONSWAP) theoretical spectrum (Hasselmann et al., 1973) is used for comparison of the measured data and is given below. 


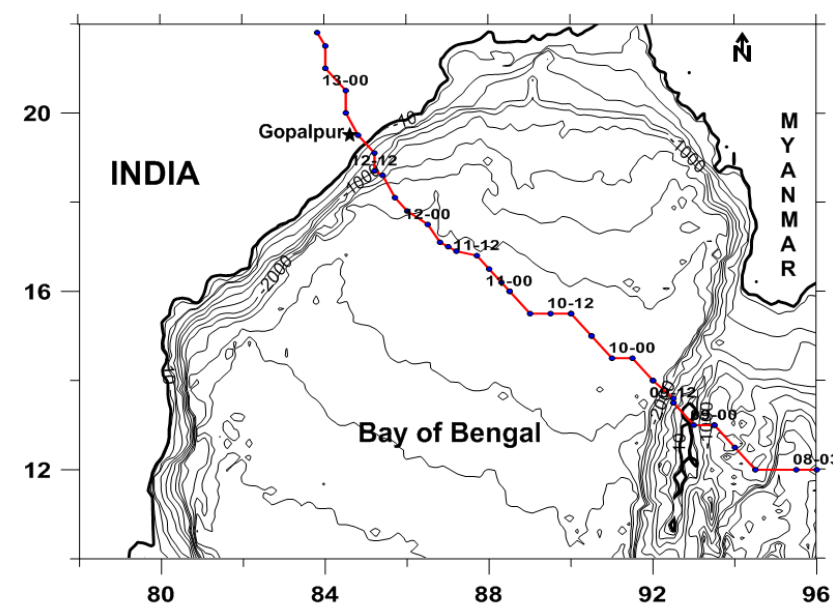

Figure 1. Track of the Cyclone Phailin from 8 October 2013 03:00 UTC to 13 October 2013 06:00 UTC.

$S(f)=\frac{\alpha g^{2}}{(2 \pi)^{4} f^{5}} \exp \left[-\frac{5}{4}\left(\frac{f}{f_{\mathrm{p}}}\right)^{-4}\right] \gamma^{\exp \left[-\frac{\left(f-f_{\mathrm{p}}\right)^{2}}{2 \sigma^{2} f_{\mathrm{p}}}\right],}$

where $\alpha$ and $\gamma$ are the JONSWAP parameters and $f_{\mathrm{p}}$ the peak frequency.

Significant wave height at the point of maximum wind is estimated using a parametric wave model (USACE, 1984) based on the following equation.

$H_{\mathrm{S}}=5.03 \exp ^{\frac{R \Delta P}{4700}}\left(1+\frac{0.29 \alpha V_{\mathrm{fm}}}{\sqrt{V_{\max }}}\right)$,

where $\Delta P=P_{n}-P_{0}, P_{n}$ is the peripheral pressure, $P_{0}$ is the mean sea level pressure at the centre of the storm, $R$ is radius of maximum wind for the storm, $V_{\max }$ is maximum wind speed and $V_{\mathrm{fm}}$ is speed of forward motion and these parameters are taken from IMD (2013).

\section{Characteristics of Cyclone Phailin}

A very severe cyclonic storm, Phailin, originated from a remnant cyclonic circulation from the South China Sea on 6 October 2013 and intensified into a deep depression on 9 October morning and further into a cyclonic storm (CS), Phailin, in the evening of the same day (IMD, 2013). Moving north-westwards, it further intensified into a severe cyclonic storm (SCS) at 03:00 UTC and into a very severe cyclonic storm (VSCS) at 06:00 UTC of 10 October over east central Bay of Bengal. The VSCS, Phailin, crossed Gopalpur coast around 17:00 UTC of 12 October 2013 with a sustained maximum surface wind speed of $200-210 \mathrm{~km} \mathrm{~h}^{-1}$ gusting to $220 \mathrm{~km} \mathrm{~h}^{-1}$ (IMD, 2013).

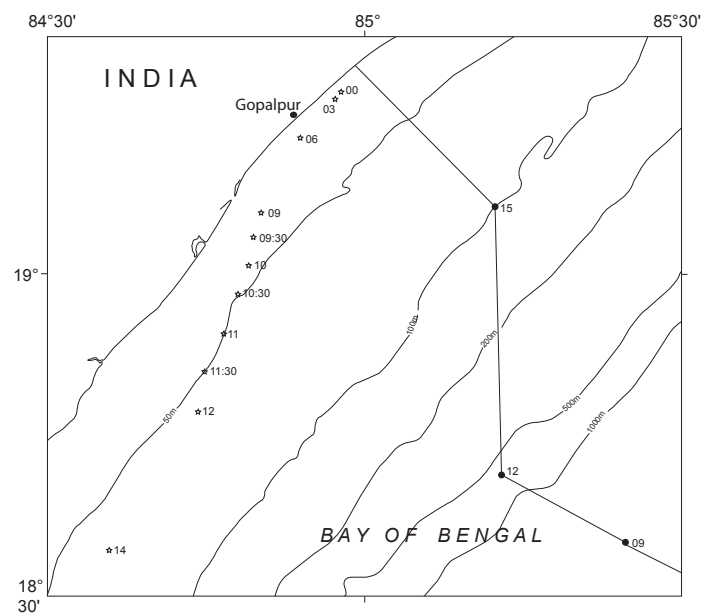

Figure 2. Cyclone track (solid circle) connected with straight line and Waverider buoy location (star) at different time on 12 October 2013. The time in UTC is indicated near the points.

\section{Results and discussions}

\subsection{Wave parameters}

On 10 October 2013, when the cyclone is $850 \mathrm{~km}$ away from the buoy location, the change in wave height was observed at the buoy location indicating the influence of cyclone (Fig. 3a and b). The average $H_{\mathrm{s}}$ during 8-9 October 2013 was $1 \mathrm{~m}$ and increased to $5.6 \mathrm{~m}$ on 12 October 2013 (Table 2). The swells generated by the cyclone reached the location before the arrival of the cyclone and resulted in an increase in the $T_{\mathrm{m}_{02}}$ (Fig. 3e). Within $54.5 \mathrm{~h}$ (from 10 October 04:00 to 12 October 10:30 UTC), $H_{\max }$ increased from 1.5 to $13.5 \mathrm{~m}$ and during the same period $H_{\mathrm{s}}$ increased from 1.1 to $7.3 \mathrm{~m}$ (Fig. 3a and c). The highest $H_{\mathrm{s}}$ measured during Cyclone Phailin is less than that measured $(8.4 \mathrm{~m}$ on 28 October 1999) in the Bay of Bengal in deep water during the passage of the Orissa super cyclone (Rajesh et al., 2005). The earlier reported maximum $H_{\mathrm{s}}$ off Gopalpur based on measured data was $2.4 \mathrm{~m}$ in 1990 (Chandramohan et al., 1993) and $3.3 \mathrm{~m}$ in 2008 (Mohanty et al., 2012).

Due to the cyclone-generated high waves, the Waverider buoy drifted from its moored position at 00:00 UTC on 12 October 2013. The global positioning system (GPS) data recorded by the buoy show that the buoy was within $70 \mathrm{~km}$ distance from the cyclone track when it recorded the maximum wave height of $13.5 \mathrm{~m}$ (Table 1). When the buoy was at $15 \mathrm{~m}$ water depth, the maximum wave height measured was $8.5 \mathrm{~m}$, which is 0.57 times the water depth and is less than the limiting value of wave height in a water depth (0.6 times the water depth) proposed for wave breaking by Massel (1966). The tide during the occurrence of high wave was $1 \mathrm{~m}$, and hence considering the tide, the maximum wave height measured was 0.53 times the water depth. 

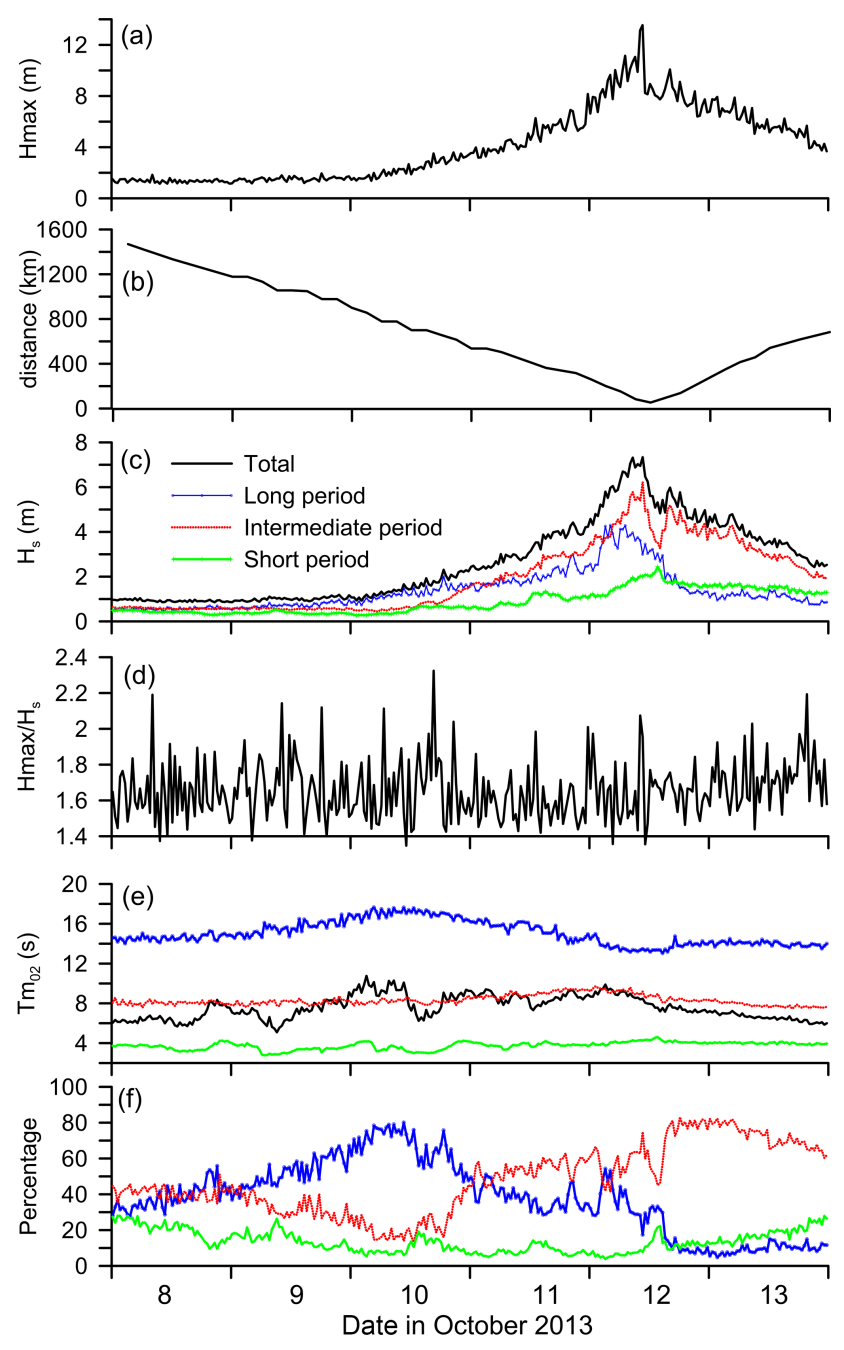

Figure 3. Variation of (a) maximum wave height, (b) distance of the cyclone from the buoy location, (c) significant wave height of long, intermediate and short period waves, (d) ratio of maximum wave height to significant wave height, (e) mean wave period of long, intermediate and short period waves and (f) percentage of long, intermediate and short period waves during 8-13 October 2013.

In the past decade, significant advances have been made in numerical modelling of hurricane-generated waves in deep water due to the availability of measured waves, mainly in the Gulf of Mexico. Fan et al. (2009) made numerical simulations of waves under Hurricane Ivan in 2004 and compared them with buoy observations and found that the original WAVEWATCH III model drag parameterisation tends to overestimate the significant wave height. Kumar et al. (2013) found that during Cyclone Thane, the maximum value of $H_{\mathrm{s}}$ estimated using a parametric wave model (USACE, 1984) for deep water conditions is $6.4 \mathrm{~m}$ whereas the measured value is $6 \mathrm{~m}$. In the present case, the value of $H_{\mathrm{s}}$ estimated using a parametric wave model (USACE, 1984) when the cyclone was close to the measurement location $(<100 \mathrm{~km})$ is 6.6 to

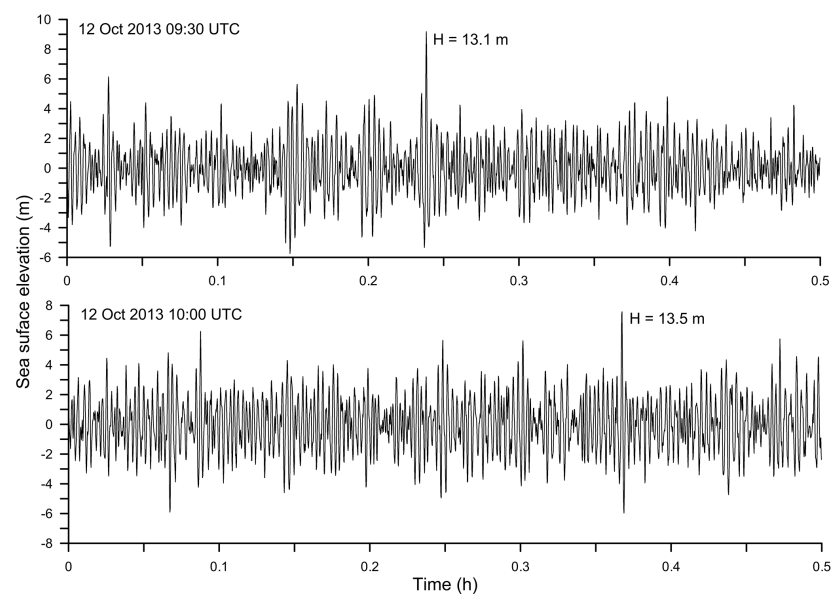

Figure 4. The time series plot of the sea surface elevation recorded at 09:30 and 10:00 UTC on 12 October 2013. The maximum wave height recorded was $13.1 \mathrm{~m}$ and $13.5 \mathrm{~m}$ and during this period, the buoy was at $50 \mathrm{~m}$ water depth.

$6.8 \mathrm{~m}$, whereas the measured value is 7.0 to $7.3 \mathrm{~m}$, indicating that the parametric wave model (USACE, 1984) estimates the wave height within $10 \%$ of the measured value during the cyclone period.

The time series plots containing the highest waves (13.5 and $13.1 \mathrm{~m}$ ) recorded are presented in Fig. 4. The height of the waves before and after the maximum wave height was 45 to $58 \%$ of the maximum value. $H_{\mathrm{s}}$ for the $30 \mathrm{~min}$ recordings containing the highest waves are 7.3 and $7.0 \mathrm{~m}$ and the ratio of $H_{\max }$ to $H_{\mathrm{s}}$ is $\sim 1.85$ and is higher than the theoretical value of 1.62 to 1.64 for 190 to 220 waves (Longuet-Higgins, 1952). During the cyclone, the ratio between $H_{\mathrm{max}}$ and $H_{\mathrm{s}}$ for the $30 \mathrm{~min}$ recordings varied from 1.4 to 2.3 , with an average value of 1.66 (Fig. 3d), and the average value measured is close to the theoretical value.

From 8 to 12 October 2013, freak waves, waves with abnormality index $\left(H_{\max } / H_{\mathrm{s}}\right)>2$, were observed eight times (Fig. 5). The number of freak waves occurring during a storm is an important parameter for marine engineers, marine workers and sailors. Freak waves sometimes feature a single steep crest, causing severe damage to offshore structures and ships (Mori et al., 2011). The abnormality index is found to increase with an increase in the kurtosis of the sea surface elevation (Fig. 5a). Mori et al. (2011) showed that the kurtosis depends on the square of the Benjamin-Feir index (BFI), but the present data did not indicate such a relationship due to the presence of multi-peaked spectra in the study region (Fig. 5b). The skewness, the degree of vertical asymmetry of the surface elevation, is found to vary with the directional width (Fig. 6). On 9 October 2013, the skewness values are less than 0.2 and on 12 October 2013, the skewness increased to 0.45 . The average directional width is 29 and $17^{\circ}$ on 9 October and 12 October 2013. As the directional width decreases the skewness increases, indicating 
Table 2. Daily mean wave parameters during 8-13 October 2013.

\begin{tabular}{|c|c|c|c|c|c|c|}
\hline \multirow[b]{2}{*}{ Parameters } & \multicolumn{6}{|c|}{ Date in October 2013} \\
\hline & 8 & 9 & 10 & 11 & 12 & 13 \\
\hline Significant wave height (m) & 0.9 & 1.0 & 1.6 & 3.3 & 5.6 & 3.6 \\
\hline Maximum wave height (m) & 1.4 & 1.5 & 2.4 & 4.8 & 8.6 & 5.7 \\
\hline Ratio of maximum and significant wave height & 1.64 & 1.67 & 1.66 & 1.59 & 1.66 & 1.72 \\
\hline Mean wave period (s) & 6.6 & 7.1 & 8.6 & 8.6 & 8.2 & 6.6 \\
\hline Peak wave period (s) & 14.4 & 16.3 & 18.4 & 13.5 & 11.2 & 8.4 \\
\hline Wave period of maximum wave height (s) & 11.1 & 13.5 & 15.9 & 12.2 & 10.4 & 8.2 \\
\hline Maximum spectral energy density $\left(\mathrm{m}^{2} \mathrm{~Hz}^{-1}\right)$ & 1.2 & 1.7 & 8.4 & 17.9 & 60.7 & 14.5 \\
\hline Spectral width parameter & 0.63 & 0.73 & 0.74 & 0.53 & 0.43 & 0.42 \\
\hline Spectral peakedness parameter & 1.4 & 1.6 & 2.7 & 1.9 & 2.6 & 2.1 \\
\hline Long period waves $(\%)$ & 38 & 52 & 67 & 38 & 25 & 10 \\
\hline Intermediate period waves $(\%)$ & 41 & 33 & 23 & 54 & 65 & 72 \\
\hline Short period waves $(\%)$ & 21 & 15 & 10 & 08 & 10 & 18 \\
\hline
\end{tabular}
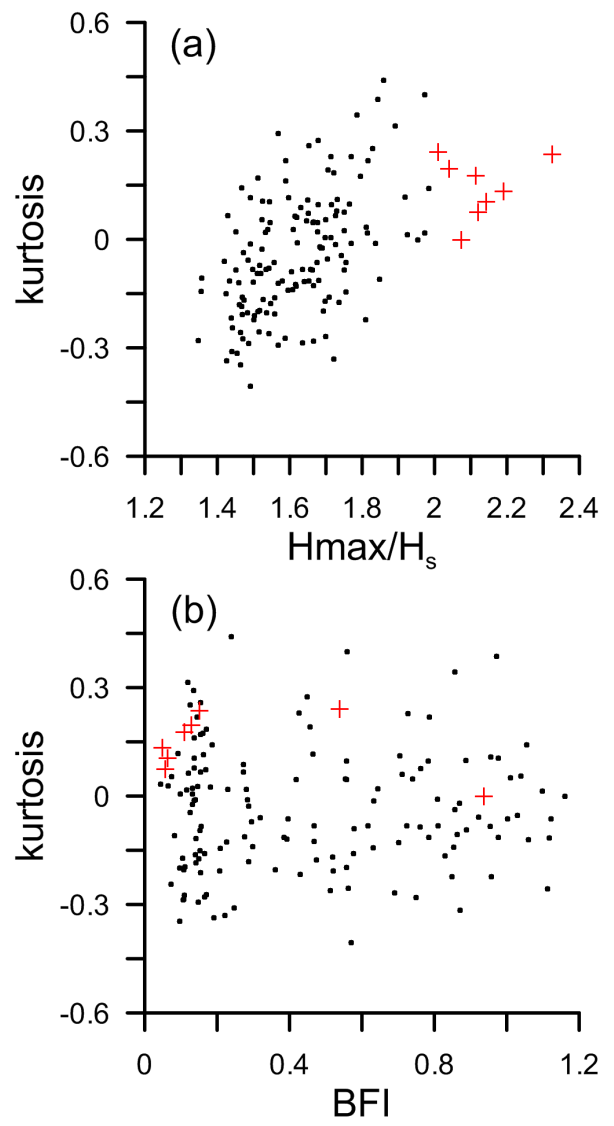

Figure 5. Plot of (a) kurtosis of the sea surface with abnormality index $\left(H_{\max } / H_{\mathrm{S}}\right)$ and (b) kurtosis of the sea surface elevation with Benjamin-Feir index (BFI). The data of the freak waves are indicated with cross symbols.

that at high sea states, the sea surface elevation is positively skewed and the directional spreading of spectral energy density at a minimum.

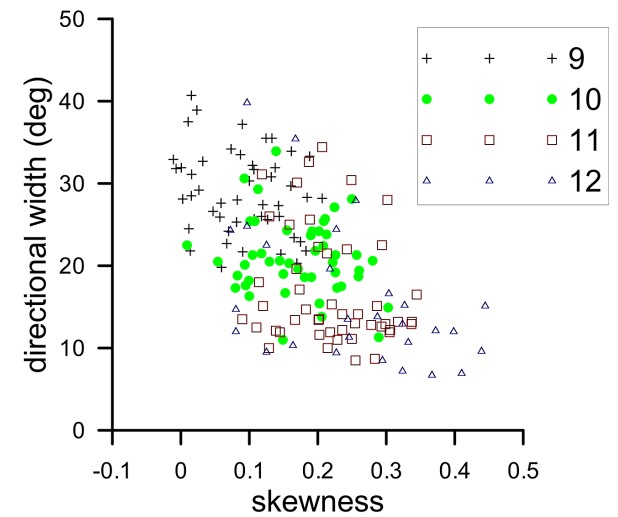

Figure 6. Variation of skewness of the sea surface elevation with directional width during 9-12 October 2013.

The ratio of the $H_{\max }$ to $H_{\mathrm{s}}$ for time series data with 3,6 , 12 and $24 \mathrm{~h}$ duration are $1.87,1.97,2.16$ and 2.41 and the respective theoretical values based on the number of waves (Longuet-Higgins, 1952) in the recording period are 1.89, $1.98,2.06$ and 2.15 (Fig. 7). Hence, it is important to consider the duration of the storm while estimating $H_{\max }$ from the $H_{\mathrm{s}}$ data. For the design of offshore structures, Goda (1985) proposed using $H_{\max }=2 H_{\mathrm{s}}$, which is slightly lower than the value (2.16) observed in the present study for the $6 \mathrm{~h}$ duration data.

The data are recorded continuously and hence the influence of data recordings at 3,6 and $12 \mathrm{~h}$ on the daily maximum $H_{\mathrm{s}}$ and the daily average $H_{\mathrm{s}}$ are studied. The study shows that data recorded with intervals of more than $3 \mathrm{~h}$ lead to missing the high waves, and the maximum $H_{\mathrm{s}}$ at 6 and $12 \mathrm{~h}$ data intervals is 8 and $23 \%$ less than that based on $0.5 \mathrm{~h}$ intervals (Table 3). Mean $H_{\mathrm{s}}$ for data with $12 \mathrm{~h}$ intervals is $10 \%$ less than the $H_{\mathrm{s}}$ data with $3 \mathrm{~h}$ intervals. 
Table 3. Mean and maximum value of significant wave height for different data recording intervals during 8-12 October 2013.

\begin{tabular}{|c|c|c|c|c|c|c|c|c|}
\hline \multirow[b]{3}{*}{ Date } & \multicolumn{8}{|c|}{ Data recording interval } \\
\hline & $0.5 \mathrm{~h}$ & $3 \mathrm{~h}$ & $6 \mathrm{~h}$ & $12 \mathrm{~h}$ & $0.5 \mathrm{~h}$ & $3 \mathrm{~h}$ & $6 \mathrm{~h}$ & $12 \mathrm{~h}$ \\
\hline & \multicolumn{4}{|c|}{$\begin{array}{l}\text { Mean significant } \\
\text { wave height }(\mathrm{m})\end{array}$} & \multicolumn{4}{|c|}{$\begin{array}{c}\text { Maximum significant } \\
\text { wave height }(\mathrm{m})\end{array}$} \\
\hline 8 & 0.9 & 0.9 & 0.9 & 0.9 & 1.0 & 1.0 & 1.0 & 1.0 \\
\hline 9 & 1.0 & 1.0 & 1.0 & 0.9 & 1.2 & 1.2 & 1.1 & 1.0 \\
\hline 10 & 1.6 & 1.6 & 1.5 & 1.3 & 2.3 & 2.3 & 2.3 & 1.7 \\
\hline 11 & 3.3 & 3.2 & 3.1 & 2.9 & 4.4 & 4.2 & 4.1 & 3.4 \\
\hline 12 & 5.6 & 5.6 & 5.5 & 5.0 & 7.3 & 7.0 & 6.7 & 5.6 \\
\hline
\end{tabular}

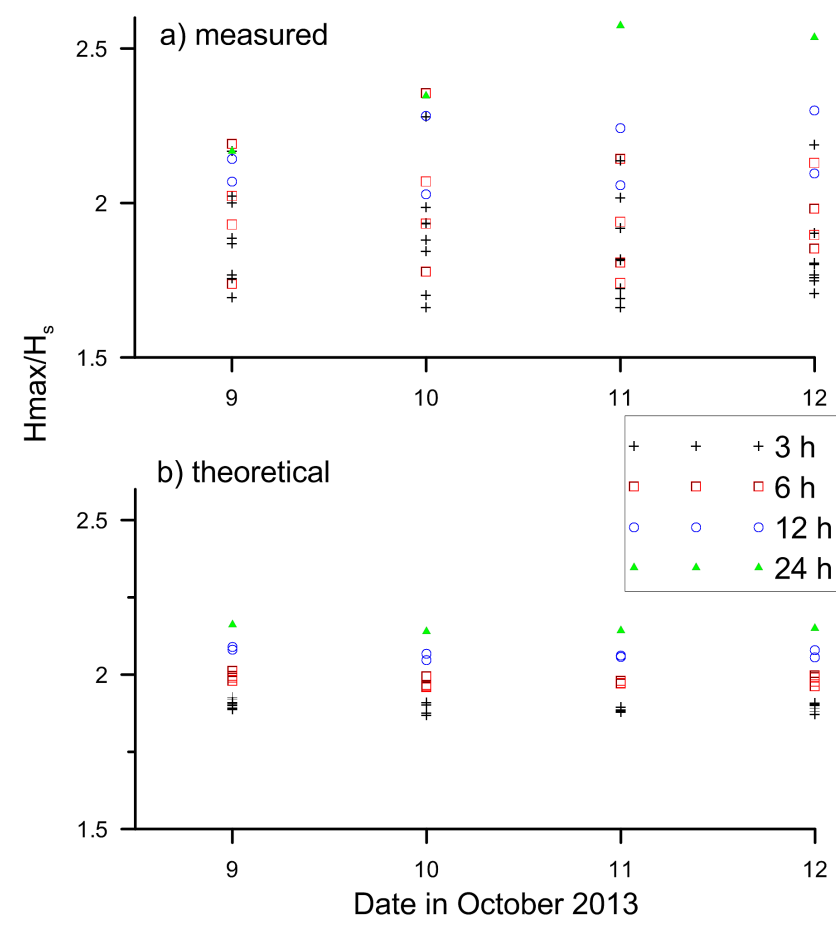

Figure 7. Ratio of maximum wave height to significant wave height (a) based on measured data and (b) estimated using the Rayleigh distribution for data collected for 3, 6, 12 and $24 \mathrm{~h}$ durations.

Individual wave heights and associated wave periods were estimated from the $30 \mathrm{~min}$ recordings during $8-12$ October 2013 and the waves were separated into swell and wind sea considering $6 \mathrm{~s}$ wave period as the separation period (Fig. 8a and b). The analysis shows that the percentage of swell and wind sea is the same $(\sim 50 \%)$ before the cyclone, and due to the influence of cyclone, the swells increased and reached a maximum $(\sim 90)$ just before the maximum $H_{\mathrm{s}}$ (Fig. 8c). Even though high local wind is present, when the cyclone is close to the buoy location, the measured waves are predominantly swells (Fig. 8c). The reason for swell domination is that swell generated in the cyclone wind regions propagates ahead of the cyclone and dominates the whole wave
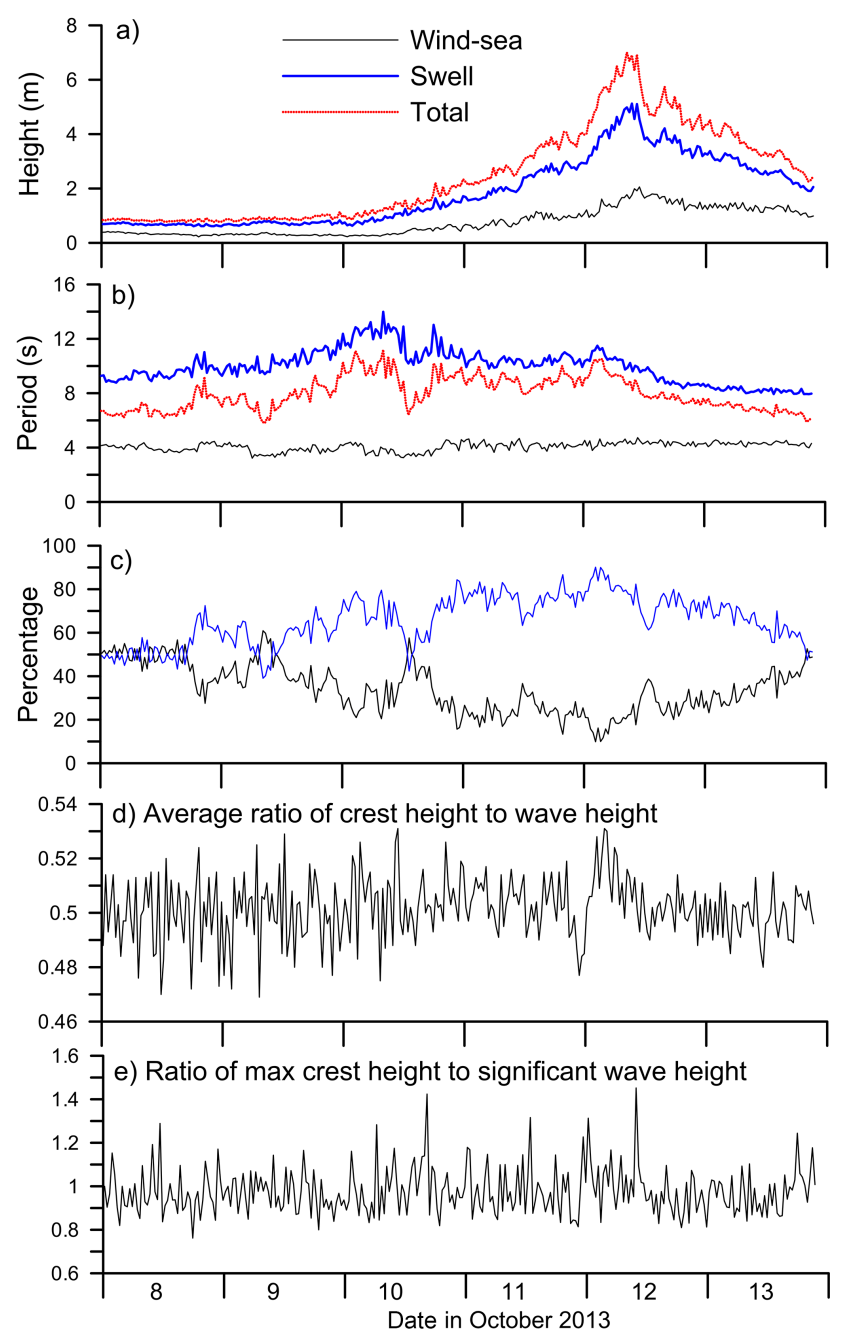

Figure 8. Variation of (a) average wave height of wind sea, swell and total, (b) average period of wind sea, swell and total, (c) percentage of wind sea and swell, (d) average ratio of crest height to wave height and (e) ratio of the maximum crest height to significant wave height in the $30 \mathrm{~min}$ recordings.

field. The cyclone took $60 \mathrm{~h}$ (10 October 2013 00:00 UTC to 12 October 12:00 UTC) to reach the wave measurement location whereas the swells generated by the cyclone took only 27 to $40 \mathrm{~h}$ (group velocities for waves with peak wave period $8 \mathrm{~s}$ and $12 \mathrm{~s}$ are 6.2 and $9.4 \mathrm{~m} \mathrm{~s}^{-1}$ ) to travel $900 \mathrm{~km}$ (distance between the cyclone position at 10 October 2013 00:00 UTC and 12 October 12:00 UTC). Previous measurements of tropical cyclones (Young, 2006; Kumar et al., 2013) also showed similar results. King and Shemdin (1978) found that cyclonic storms cause generation of low-frequency waves and these waves can propagate ahead of the cyclone.

The average ratio of crest height to wave height of all waves in the $30 \mathrm{~min}$ recordings varied from 0.47 to 0.53 (Fig. 8d). The ratio of crest height to wave height of the high wave recorded during the cyclone was 0.6 to 0.7 (Fig. 9a 

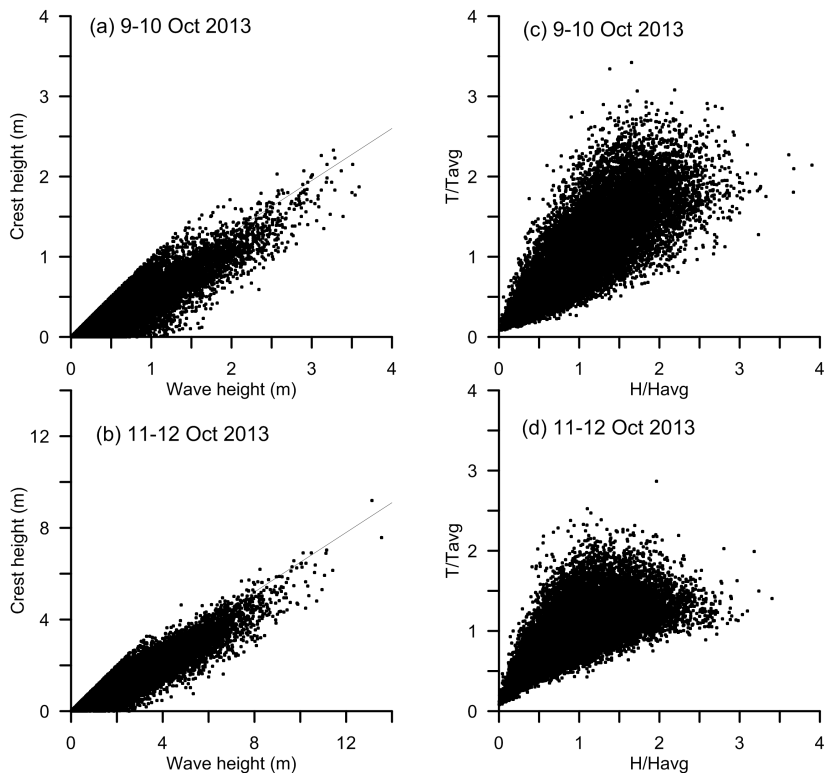

Figure 9. Relationship between crest height and wave height (a) before the cyclone and (b) during the cyclone. Joint distribution of normalised period and height (c) before the cyclone and (d) during the cyclone.

and $b$ ) and is similar to the value (0.65) observed during Cyclone Thane (Kumar et al., 2013). During Cyclone Thane, the maximum $H_{\mathrm{s}}$ measured was $6 \mathrm{~m}$ and occurred on 29 December 2011. In the present study, the ratio of the maximum crest height to the significant wave height in the $30 \mathrm{~min}$ recordings varied from 0.8 to 1.5 with an average value of 1 (Fig. 8e).

The joint distribution of wave height and period measured on 12 October 2013 09:30 and 10:00 UTC shows that high waves $(H>8 \mathrm{~m})$ are associated with $11-13 \mathrm{~s}$ wave periods and waves with heights of 6 to $8 \mathrm{~m}$ are associated with periods of 9 to $14 \mathrm{~s}$ (Fig. 10). The scatter plot of normalised wave height and normalised wave period during 9-10 October and 11-12 October is presented in Fig. 9c and d. The shape of the distribution is different before the cyclone and during the cyclone. Before the cyclone, the increase in wave period was observed with an increase in wave height. The period distribution narrows as the wave height increases during the cyclone period, and the long period waves $(T>18 \mathrm{~s})$ measured are with height less than $4 \mathrm{~m}$. The steepness of the waves measured is less than the limiting steepness value during the cyclone (Fig. 11a). The curve for the greatest wave height as a function of wavelength and water depth derived by Fenton (1990) also shows that the measured waves are not fully breaking waves (Fig. 11b and c).

Following Bromirski et al. (2005), the wave spectral energy is divided into three bands, that is (1) short period (wave period, $T<6 \mathrm{~s}$, is dominated by local seas), (2) long period $(T>12 \mathrm{~s}$, results primarily from swell) and (3) intermediate period $(6 \mathrm{~s} \leq T \leq 12 \mathrm{~s}$, probably results from a mixture (a) 12 Oct 2013 09:30 UTC

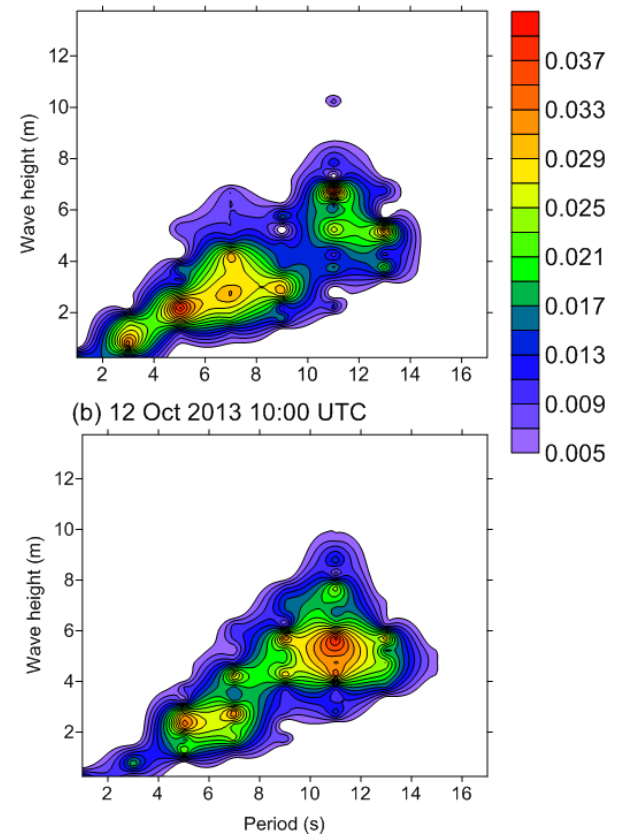

Figure 10. Joint distribution of wave height and period of the high waves. The contours indicate the probability values.

of local and regional wind forcing), and the variations were studied. Before the influence of the cyclone, the waves were a combination of 21,41 and $38 \%$ short period, intermediate and long period waves and during the cyclone these values changed to 10,62 and $28 \%$ (Fig. 3f). The contribution of long period waves to the total $\mathrm{H}_{s}$ increased $(67 \%)$ on 10 October 2013, when the cyclone was in the Andaman Sea (Fig. 1), but when the cyclone was close to the buoy location, the contribution of intermediate period waves was at a maximum (Fig. 3c). Due to the dominance of the intermediate period waves, the average period of the waves decreased during the cyclone (Fig. 3e).

\subsection{Wave spectra}

Since there is a large variation in spectral energy density (0.5 to $122.4 \mathrm{~m}^{2} \mathrm{~Hz}^{-1}$ ) during $8-13$ October (Fig. 12a), the normalised spectral energy density is plotted on a timefrequency grid to understand the contribution of waves with different frequencies during the cyclone period (Fig. 13a). On 10 October 2013, since the swells reached the measurement site before the cyclone, the wave spectra changed from broad to narrowband and the spectral energy density was within narrow range of frequencies $(0.05$ to $0.07 \mathrm{~Hz})$. During this period, the spectral peakedness parameter $\left(Q_{\mathrm{p}}\right)$ increased (>3) (Fig. 12b), indicating a very narrow spectrum and the peak wave period increased (>16s) (Fig. 12c). $Q_{\mathrm{p}}$ increased as the bandwidth became narrow (fully developed wind seas have $Q_{\mathrm{p}} \approx 2$, whereas broad-banded swells have 


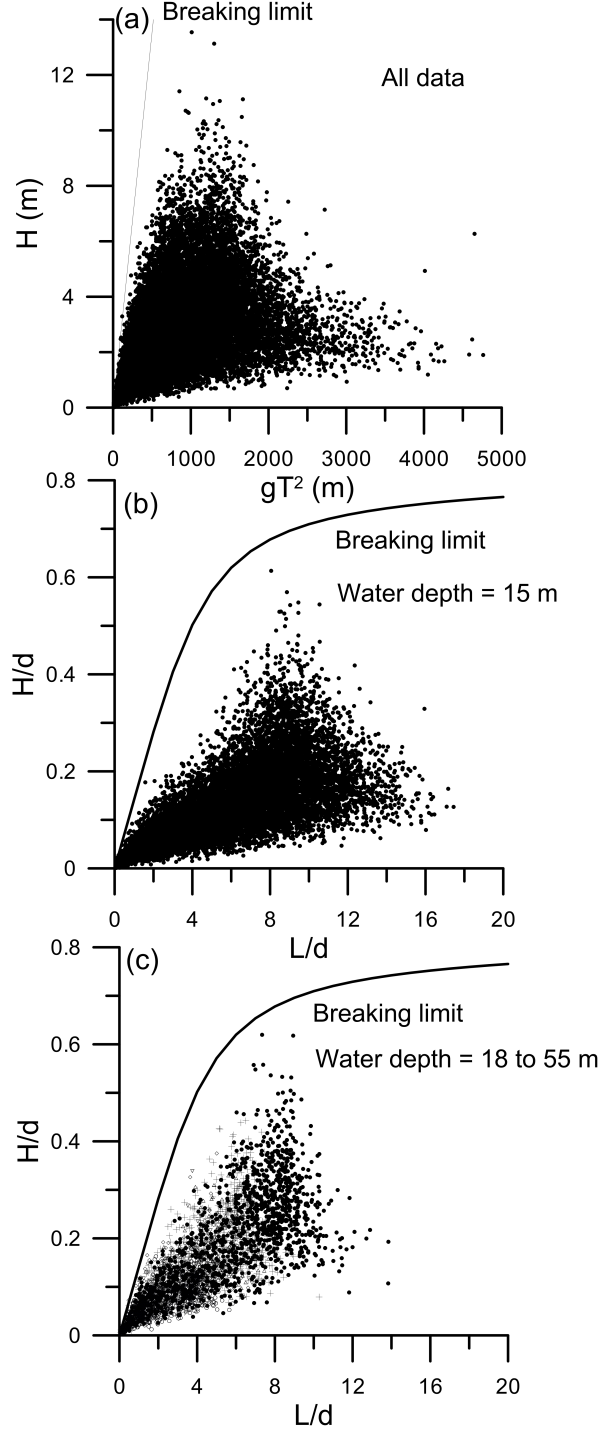

Figure 11. The graph showing the breaking limit based on (a) Ochi (1990) for all data, (b) Fenton (1990) for data at $15 \mathrm{~m}$ water depth and (c) Fenton (1990) for data at 18 to $55 \mathrm{~m}$ water depth.

values > 2). Goda (1976) reported $Q_{\mathrm{p}}$ values of 2 to 3 from single-peaked spectra recorded in the Japanese coastal waters. On 11 October 2013, due to the influence of cyclone winds, the peak frequency shifted from 0.06 to $0.09 \mathrm{~Hz}$ and a broad-banded wave spectrum was observed, due to the combined wind sea and swell. On 12 October 2013, during the cyclone period the mean value of the spectral peakedness parameter was around 2.6, indicating that the spectrum was narrow-banded similar to the observation on 10 October 2013. On 12 October 2013, the spectral width parameter decreased $(<0.5)$ also indicating narrowband wave spectra (Fig. 12d). The spectral width parameter varies from 0 to 1 , and has smaller values for narrower spectra. When the cyclone was close to the buoy, due to the influence of high local
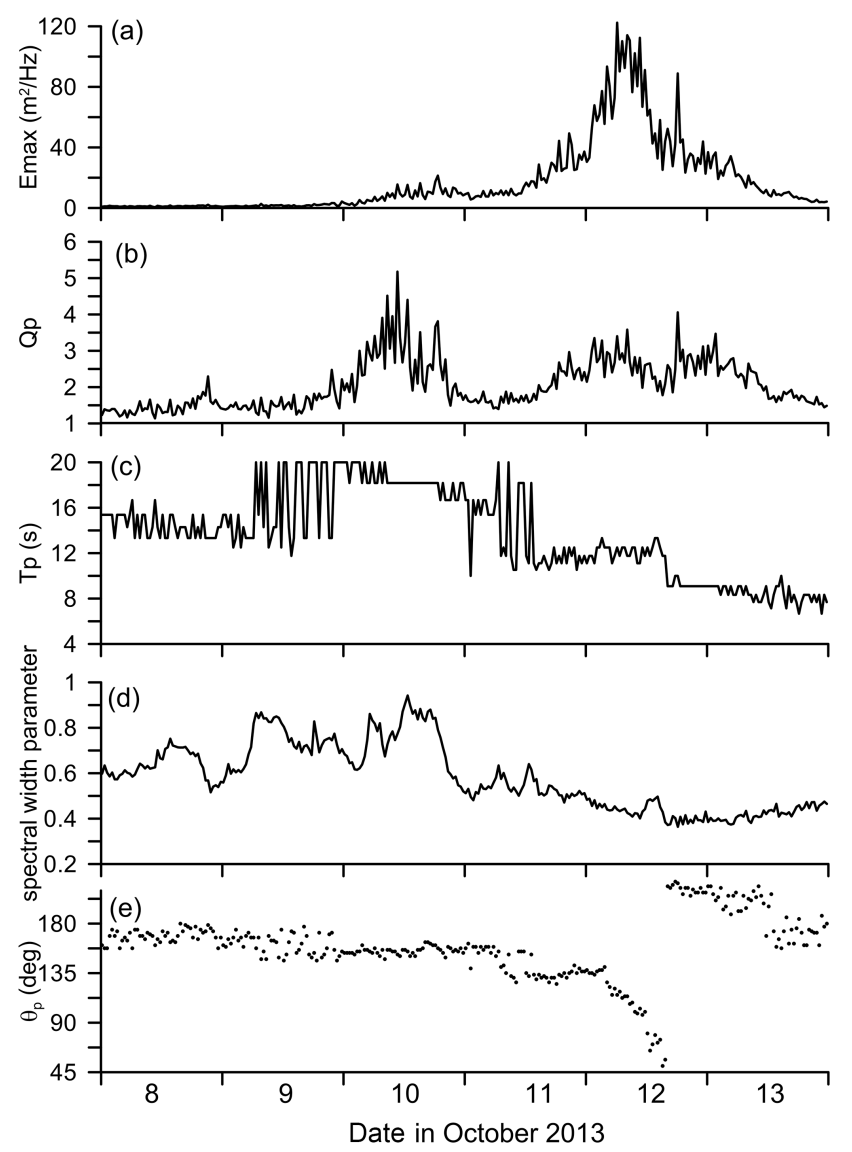

Figure 12. Variation of (a) maximum spectral energy density, (b) spectral peakedness parameter, (c) peak wave period, (d) spectral width parameter and (e) mean wave direction during 8-13 October 2013.

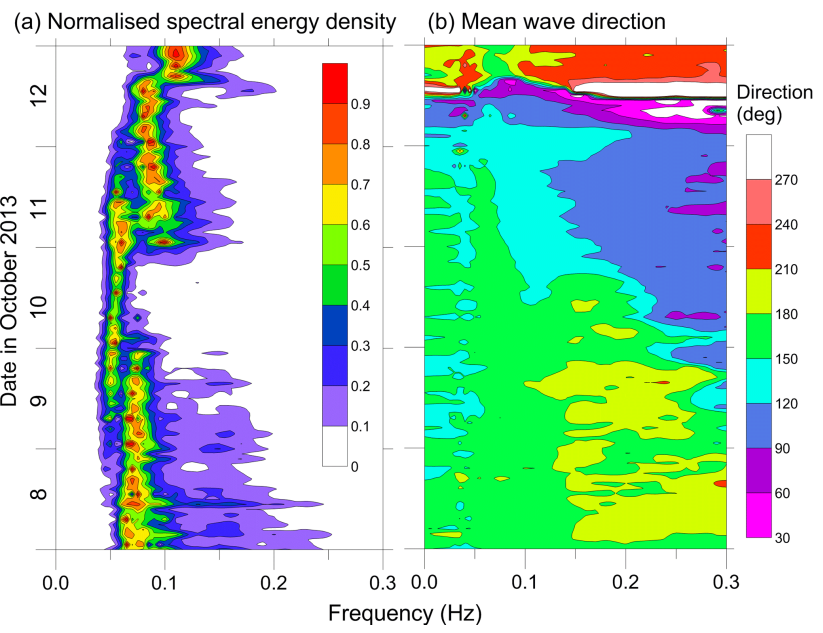

Figure 13. Time history of (a) normalised spectral energy density and (b) mean wave direction with frequency from 8 to 12 October 2013. 


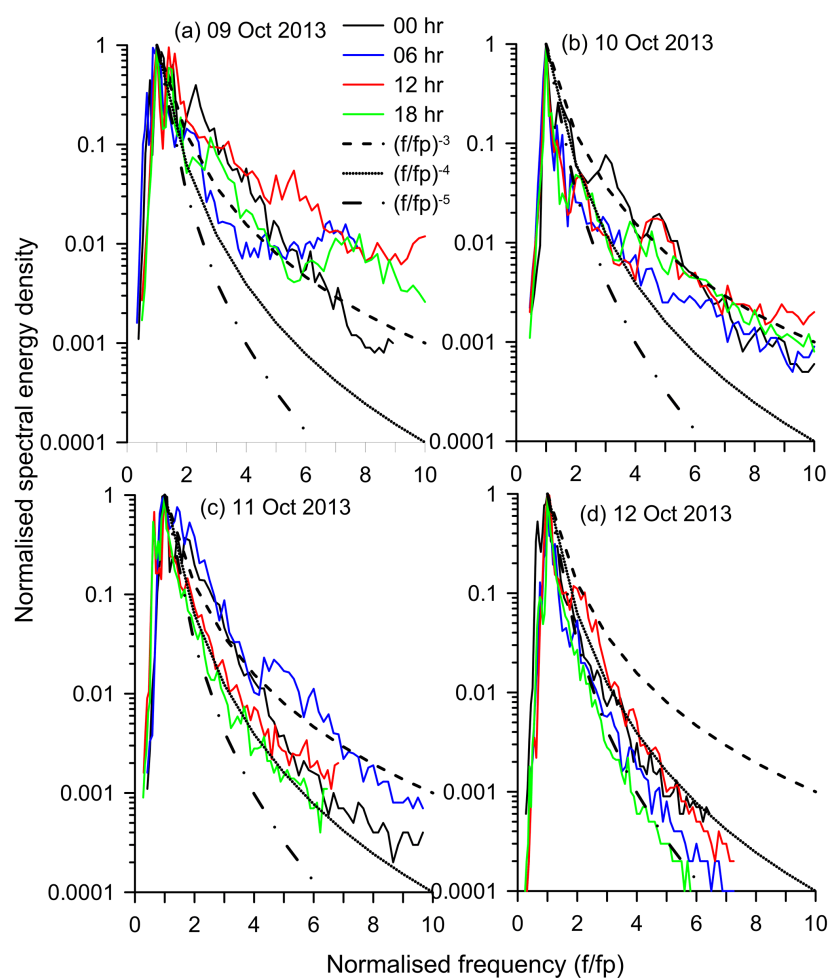

Figure 14. The normalised wave spectra during 9-12 October at different times. The slope of the high-frequency part of the spectra before the cyclone is $f^{-3}$ and during the cyclone it is between $f^{-4}$ and $f^{-5}$.

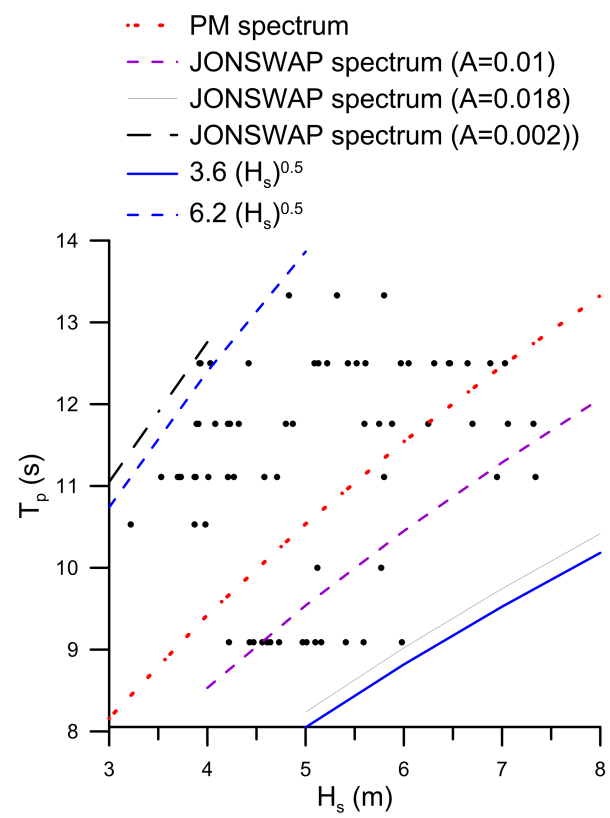

Figure 15. Variation of peak wave period $\left(T_{\mathrm{p}}\right)$ with significant wave height $\left(H_{\mathrm{S}}\right)$ during 11-12 October 2013. The various theoretical formulations are also presented in the figure.

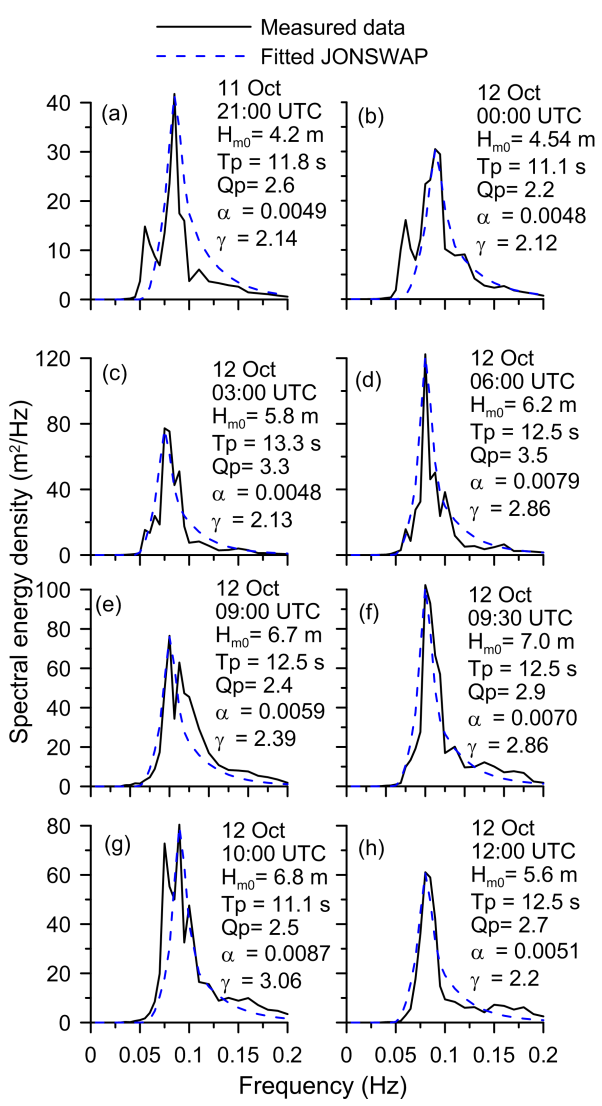

Figure 16. Wave spectra based on measurement and the fitted JONSWAP spectra during the period (11-12 October 2013) when the waves are high due to the influence of Cyclone Phailin.

winds and swells, broadband spectrum should have been observed since the wind sea spectrum was broader than the narrow swell spectrum, but the measured spectra indicate narrowband spectra, due to the dominance of intermediate period waves. Before the cyclone, the mean wave directions of the waves were $150-180^{\circ}$ (Fig. 12e). During the cyclone, the mean wave direction initially shifted to $120-150^{\circ}$ and then to $90-120^{\circ}$. The direction of high-frequency waves also shifted from $180-210^{\circ}$ to $90-120^{\circ}$ (Fig. 13b).

The measured spectral shape in the high-frequency region lies between the curves proportional to $f^{-5}$ and $f^{-3}$ (where $f$ is the frequency), is between $f^{-4}$ and $f^{-5}$ when the cyclone is close to the measurement location and is close to $\mathrm{f}^{-3}$ before the cyclone (Fig. 14). Young and Verhagen (1996) found that the exponent of the spectral curve in the highfrequency region is approximately -5 in deep water and around -3 in finite depth.

It is important to know the value of $T_{\mathrm{p}}$ associated with the $H_{\mathrm{s}}$ for certain designs and hence the variation of $T_{\mathrm{p}}$ with $H_{\mathrm{s}}$ is studied along with the theoretical formulations. The $T_{\mathrm{p}} /\left(H_{\mathrm{s}}\right)^{0.5}$ varied between 3.6 and 6.2 during the cyclone period (Fig. 15) and is within the values 3.6 and 5 recommended (DNV, 2011) to use the JONSWAP spectrum 


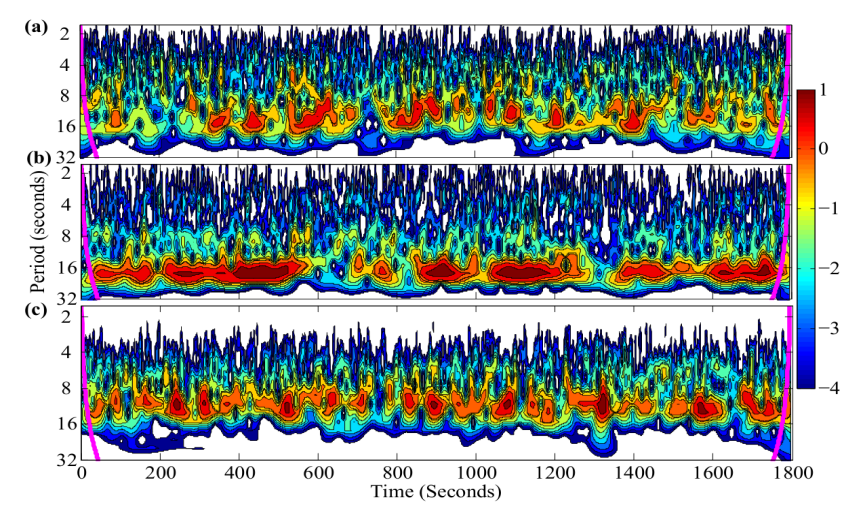

Figure 17. Wavelet power spectrum (a) before cyclone (8 October 00:00 UTC), (b) middle lifespan of cyclone (10 October 12:00 UTC) and (c) cyclone close to the buoy location (12 October 10:00 UTC).

(Hasselmann et al., 1973). Hence, the single-peaked wave spectra of high waves can be represented by the JONSWAP spectrum with modified parameter $\alpha$ (Phillips constant) and $\gamma$ (Fig. 16). When the spectrum is double-peaked in nature, the JONSWAP spectrum will not provide good fit. The fitted JONSWAP spectrum is obtained by selecting the parameter $\alpha$ and $\gamma$ of the JONSWAP spectrum such that the peak of the spectrum agrees. During $8-12$ October, the average values of the JONSWAP parameters, $\alpha$ and $\gamma$, are 0.003 and 1.7 and are close to the observations ( 0.0027 and 1.63) of Kumar and Kumar (2008) and Kumar et al. (2013). The estimated average value of the JONSWAP parameters, $\alpha$ and $\gamma$, are less than the generally recommended values of 0.0081 and 3.3 respectively. Ochi (1990) found that the JONSWAP spectrum provided good approximation to the data for the unimodel spectra with the JONSWAP parameters of $\alpha=0.023$ and $\gamma=2.2$.

The wavelet power spectrum of $0.5 \mathrm{~h}$ recorded data during the cyclone period is examined to know the variation of the period of individual waves (Fig. 17): once before the cyclone, once during the middle lifespan of the cyclone and once when the cyclone is close to the buoy location. In normal conditions, the wave period varied between 8 and $16 \mathrm{~s}$ (Fig. 17a), but when the cyclone is $900 \mathrm{~km}$ away from the buoy location, the wave period shifted to 16 to $24 \mathrm{~s}$ (Fig. 17b). These long period waves has no significant influence on the wave height and spectral wave energy since they were low-amplitude waves. Since the dissipation of the swell decreases with decreasing wave height (Ardhuin et al., 2009), the long period waves generated by cyclones can propagate further with little dissipation. When the cyclone hit the buoy location, the predominant wave period again shifted back to the range of 8 to $16 \mathrm{~s}$ due to the increase of wind sea due to the cyclone's winds (Fig. 17c).

\section{Concluding remarks}

The maximum wave height $(8.5 \mathrm{~m})$ measured when the buoy was at $15 \mathrm{~m}$ water depth is 0.57 times the water depth and is less than the limiting wave height ( 0.6 times the water depth). The steepness of the measured waves during the cyclone is less than the limiting steepness value. During the cyclone period, the maximum significant wave height of $7.3 \mathrm{~m}$ and maximum wave height of $13.5 \mathrm{~m}$ were measured at $50 \mathrm{~m}$ water depth when the cyclone was $70 \mathrm{~km}$ away from the buoy location. Eight freak wave events were observed during the study period. The average ratio of the maximum wave height to significant wave height during the cyclone is 1.66 and the ratio of the crest height to wave height of the highest wave recorded is 0.6 to 0.7 . When the cyclone was close to the buoy location, narrowband spectra were observed, due to the dominance of intermediate period waves, and the highfrequency face of the wave spectrum is proportional to $f^{-3}$ before the cyclone and is between $f^{-4}$ and $f^{-5}$ during the cyclone.

Acknowledgements. The authors acknowledge the financial support given by the Earth System Science Organization (ESSO), Indian National Centre for Ocean Information Services (INCOIS), Ministry of Earth Sciences, government of India to conduct this research. The authors also acknowledge the director of the CSIRNational Institute of Oceanography, Goa, and of INCOIS for the encouragement provided to carry out the study. We thank Chilka Development Authority, Bhubaneswar, for help during the measurement. The authors would also like to thank Hubert Branger and the anonymous reviewer who greatly contributed to the improvement of this manuscript. This is NIO contribution 5628 and INCOIS contribution 201.

Topical Editor V. Kotroni thanks H. B. Branger and one anonymous referee for their help in evaluating this paper.

\section{References}

Ardhuin, F., Chapron, B., and Collard, F.: Observation of swell dissipation across oceans, Geophys. Res. Lett., 36, L06607, doi:10.1029/2008GL037030, 2009.

Babanin, A. V., Hsu, T.-W., Roland, A., Ou, S.-H., Doong, D.-J., and Kao, C. C.: Spectral wave modelling of Typhoon Krosa, Nat. Hazards Earth Syst. Sci., 11, 501-511, doi:10.5194/nhess11-501-2011, 2011.

Barstow, S. B. and Kollstad, T.: Field trials of the directional waverider, in: Proceedings of the First International Offshore and Polar Engineering Conference, Edinburgh, III, 55-63, 1991.

Bromirski, P. D., Cayan, D. R., and Flick, R. E.: Wave spectral energy variability in the northeast Pacific, J. Geophys. Res., 110, C03005, doi:10.1029/2004JC002398, 2005.

Chandramohan, P., Kumar, V. S., and Nayak, B. U.: Coastal processes along the shorefront of Chilka lake, Indian J. Mar. Sci., 22, 268-272, 1993.

Chu, P. C. and Cheng, K. F.: South China Sea Wave Characteristics during Typhoon Muifa Passage in Winter 2004, J. Oceanogr., 64, 1-21, 2008. 
DNV: Modelling and analysis of marine operations, Recommended Practice DNV-RP-H103, DET NORSKE VERITAS, 150 pp., 2011.

Fan, Y., Ginis, I., Hara, T., Wright, C. Y., and Walsh, E. J.: Numerical Simulations and Observations of Surface Wave Fields under an Extreme Tropical Cyclone, J. Phys. Oceanogr., 39, $2097-$ $2116,2009$.

Fenton, J. D.: Non-linear wave theories, in: The Sea, Ocean Engineering Science, Vol. 9, Part A, edited by: Le Mehaute, B. and Hanes, D. M., Pub. Wiley Interscience, 1990.

Goda, Y.: Numerical experiments on wave statistics with spectral simulation, Report Port and Harbour Research Institute, Japan, 9, 3-57, 1970.

Goda, Y.: On Wave Groups, Proc. Conf. Behaviour of Offshore Structures, Trondheim, Norway, Vol. 1, 115-128, 1976.

Goda, Y.: Random Seas and the design of maritime structures, University of Tokyo Press, Tokyo, 1985.

Hasselmann, K., Barnett, T. P., Bouws, E., Carlson, H., Cartwright, D. E., Enke, K., Ewing, J. A., Gienapp, H., Hasselmann, D. E., Kruseman, P., Meerburg, A., Muller, P., Olbers, D. J., Richter, K., Sell, W., and Walden, H.: Measurements of wind-wave growth and swell decay during the Joint North Sea Wave Project (JONSWAP), Deutsche. Hydrograph., Z, A12, 95, 1973.

IMD: Very Severe Cyclonic Storm, PHAILIN over the Bay of Bengal (8-14 October 2013): A Report, India meteorological department, Earth System Science Organisation, Ministry of Earth Sciences Government of India Cyclone Warning Division, New Delhi, available at: http://www.imd.gov.in/section/ nhac/dynamic/phailin.pdf (last access: 20 December 2013), October 2013.

King, D. B. and Shemdin, O. H.: Radar observations of hurricane wave directions, Proc. 16th Int. Conf. Coastal Eng. Hamburg, Germany, ASCE, 209-226, 1978.

Kuik, A. J., Vledder, G., and Holthuijsen, L. H.: A method for the routine analysis of pitch and roll buoy wave data, J. Phys. Oceanogr., 18, 1020-1034, 1988.

Kumar, V. S. and Kumar, K. A.: Spectral representation of high shallow water waves, Ocean. Eng., 35, 900—911, 2008.
Kumar, V. S., Glejin, J., Dubhashi, K. K., and Nair, T. M. B.: Waves during THANE cyclone, Bay of Bengal, Natural Hazards, 69, 509-522, doi:10.1007/s11069-013-0713-z, 2013.

Longuet-Higgins, M. S.: On Statistical Distribution of the Heights of Sea Waves, J. Mar. Res., 11, 245-266, 1952.

Massel, S. R.: On the largest wave height in water of constant depth, Ocean. Eng., 23, 553-573, 1966.

Mohanty, P. K., Patra, S. K., Bramha, S., Seth, B., Pradhan, U., Behera, B., Mishra, P., and Panda, U. S.: Impact of Groins on beach morphology: A case study near Gopalpur Port, East Coast of India, J. Coast. Res., 28, 132-142, 2012.

Mori, N., Onorato, M., and Janssen, P. A. E. M.: On the Estimation of the Kurtosis in Directional Sea States for Freak Wave Forecasting, J. Phys. Oceanogr., 41, 1484-1497, 2011.

Ochi, M. K.: Stochastic description of offshore environment, Water Waves Kinematics, Kluwer, Academic, 31-56, 1990.

PrasadKumar, B. and Stone, G. W.: Numerical Simulation of Typhoon Wind Forcing in the Korean Seas Using a Spectral Wave Model, J. Coastal Res., 23, 362-373, 2007.

Rajesh, G., JossiaJoseph, K., Harikrishnan, M., and Premkumar, K.: Observations on extreme meteorological and oceanographic parameters in Indian seas, Curr. Sci., 88, 1279-1282, 2005.

Soomere, T., Behrens, A., Tuomi, L., and Nielsen, J. W.: Wave conditions in the Baltic Proper and in the Gulf of Finland during windstorm Gudrun, Nat. Hazards Earth Syst. Sci., 8, 37-46, doi:10.5194/nhess-8-37-2008, 2008.

USACE: Shore Protection Manual, Department of the Army, U.S. Corps of Engineers, Washington DC, 3.81-3.84, 1984.

Xu, F., Perrie, W., Toulany, B., and Smith, P. C.: Wind-generated waves in Hurricane Juan, Ocean. Model., 16, 188-205, 2007.

Young, I. R.: Directional spectra of hurricane wind-waves, J. Geophys. Res., 111, C08020, doi:10.1029/2006JC003540, 2006.

Young, I. R. and Verhagen, L. A.: The growth of fetch limited waves in water of finite depth. Part I: Total energy and peak frequency, Coast. Eng., 29, 47-78, 1996. 